\title{
TINGKAT KONTAMINASI MIKROBA PADA BEBERAPA UNIT PENGOLAHAN IKAN ASAP PINEKUHE DI KABUPATEN SANGIHE
}

\section{LEVEL OF MICROBIAL CONTAMINATION IN SEVERAL PINEKUHE SMOKED FISH PROCESSING UNITS IN SANGIHE DISTRICT}

\author{
Ely John Karimela ${ }^{1}$, Jeffri A Mandeno ${ }^{1}$ \\ ${ }^{1}$ Jurusan Perikanan dan Kebaharian, \\ Politeknik Negeri Nusa Utara, Tahuna \\ Korespondensi: karimelaelyjohn@gmail.com
}

\begin{abstract}
One of the products processed by smoked fisheries owned by fishermen regency of Sangihe Island is Pinekube. This research aims to determine the level of microbial contamination in the smoked fish Pinekube processed fishermen regency of Sangihe Islands. Sampling was taken randomly in some of the fish processing units of Pinekuhe smoke. Observation of the deterioration of the quality of fish products Pinekube, observed through the test of Total Plate Count (TPC), total mould, and total of Staphylococcus sp. The results showed that the TPC value of all processors meets SNI standards. TPC value of $\mathrm{A}, \mathrm{B}, \mathrm{C}$, and D processors, respectively, $1,3 \times 10^{4} \mathrm{CFU} / \mathrm{G}, 2,6 \times 10^{4} \mathrm{CFU} / \mathrm{G}, 6,9 \times 10^{4}$, and $1,2 \times 10^{4} \mathrm{CFU} / \mathrm{g}$. The total observation of Staphylococcus sp. on processor $\mathrm{A}$ and processor $\mathrm{B}$ generates a value of 0 , while processor $\mathrm{C}$ has a total value of $1.1 \times 10^{2} \mathrm{TVC} / \mathrm{G}$ and processor $\mathrm{D}$ has a total value of Staphylococcus sp. 1,2 $\times 10^{2} \mathrm{TVC} / \mathrm{g}$. The total number of bacteria, the total amount of mould, and the total number of Staphylococcus sp. Still qualify SNI, except Staphylococcus sp. on processor C and processor D exceeds the amount required by the Indonesian National Standard on the limits of contamination microbes in smoked fish.
\end{abstract}

Keywords: Pinekuhe, total bacteria, total fungi, total Staphylococcus sp.

\begin{abstract}
ABSTRAK
Salah satu produk hasil olahan perikanan asap yang dimiliki oleh nelayan Kabupaten Kepulauan Sangihe adalah Pinekuhe. Penelitian ini bertujuan untuk mengetahui tingkat kontaminasi mikroba pada ikan asap Pinekube hasil olahan nelayan Kabupaten Kepulauan Sangihe. Pengambilan sampel diambil acak dibeberapa unit pengolah ikan asap Pinekuhe. Pengamatan kemunduran mutu produk ikan asap Pinekube, diamati melalui uji Total Plate Count (TPC), total kapang, dan total Staphylococcus sp. Hasil penelitian menunjukkan bahwa nilai TPC pada semua pengolah memenuhi standar SNI. Nilai TPC pada pengolah A, B, C, dan D, berturut-turut sebesar 1,3 x 104 CFU/g, 2,6 x $10^{4} \mathrm{CFU} / \mathrm{g}, 6,9 \times 10^{4}$, dan 1,2 x $10^{4} \mathrm{CFU} / \mathrm{g}$. Hasil pengamatan total Staphylococcus sp. pada pengolah A dan pengolah B menghasilkan nilai 0 , sedangkan pengolah C memiliki nilai total yaitu 1,1 × $10^{2} \mathrm{TVC} / \mathrm{g}$ dan pengolah D memiliki nilai total Staphylococcus sp. 1,2 × $10^{2}$ TVC/g. Jumlah total bakteri, jumlah total kapang, dan jumlah total Staphylococcus sp. masih memenuhi syarat SNI, kecuali Staphylococcus sp. pada Pengolah C dan Pengolah D melebihi jumlah yang dipersyaratkan oleh Standar Nasional Indonesia mengenai batas cemaran mikroba pada ikan asap.
\end{abstract}

Kata kunci : Pinekuhe, total bakteri, total kapang, total Staphylococcus sp. 


\section{PENDAHULUAN}

Indonesia kaya akan berbagai jenis produk tradisional yang memiliki kekhasan atau keunikan dari segi bentuk, bau, dan rasa. Produk tradisional dari suatu daerah sulit untuk ditemukan di daerah lain, kecuali untuk produk tertentu yang sudah dikenal secara luas, seperti ikan asap (Sulistijowati et al. 2011). Pengasapan ikan ditujukan untuk pengawetan, akan tetapi peran tersebut kini telah bergeser ke arah pembentukan flavour, warna, dan aroma khas ikan asap (Prasetyo et al. 2015). Pengasapan ikan merupakan salah satu metode pengawetan dan pengolahan yang telah banyak dimanfaatkan oleh masyarakat di Sulawesi Utara termasuk di daerah Sangihe.

Salah satu produk hasil olahan perikanan asap yang dimiliki oleh nelayan Kabupaten Kepulauan Sangihe adalah Pinekuhe. Pinekuhe adalah nama lokal atau sebutan untuk produk ikan layang asap Decapterus $s p$, yang merupakan produk olahan lokal yang memiliki rasa dan aroma asap yang khas. Ikan asap tersebut disebut Pinekuhe karena bentuknya yang unik, dibentuk dengan cara ditekuk atau dilipat. Ikan asap Pinekuhe ini juga disebut ikan kodok karena bentuknya yang menyerupai kodok (Karimela et al. 2013). Produk ini diolah dengan cara pengasapan tradisional dalam industri skala rumah tangga, dengan pelaku usaha kebanyakan adalah nelayan dan ibu rumah tangga, yang pemasarannya hanya ada di pasar tradisional. Selain bentuknya yang unik, ada beberapa faktor kemunduran mutu, baik dari faktor mutu ikan itu sendiri maupun dari orang yang menanganinya. Kemunduran mutu secara mikrobiologis merupakan bentuk kerusakan yang sangat merugikan terhadap hasil perikanan serta dapat menimbulkan penyakit dan racun (Teurupun et al. 2013).

Kekurangan dari para pengolah ikan khususnya ikan asap Pinekuhe adalah kurangnya cara penanganan yang baik sehingga mempengaruhi mutu dan daya simpan. Karimela et al. (2013) menyatakan bahwa total bakteri dan total Staphylococcus $s p$ merupakan bakteri yang paling dominan $(85,22 \%)$ mengkontaminasi produk ikan Pinekuhe asap.

Penelitian tentang total bakteri, total Staphylococcus $s p$ dan total kapang pada ikan Pinekuhe asap sangat penting dalam menyatakan suatu mutu produk Pinekuhe. Penelitian ini bertujuan untuk menentukan mutu produk ikan asap Pinekuhe hasil olahan nelayan Kabupaten Kepulauan Sangihe yang dilihat dari uji total bakteri, total Staphylococcus $s p$, dan total kapang.

\section{METODE PENELITIAN}

\section{Bahan dan alat}

Bahan yang digunakan dalam penelitian ini yaitu ikan asap Pinekuhe. Bahan kimia yang digunakan untuk analisis yaitu, nutrient agar (Himedia), akuades, manitol salt agar (Merck), potato dextroce agar (Merck). Alat yang digunakan yaitu micropippete (Dummo), cawan petri, tabung reaksi, inkubator (YCO-N01), magnetic stirer (Wina Type 206), desikator, laminary flow (Panasonic), dan autoclave (Midnif).

\section{Metode penelitian}

Sampel yang digunakan adalah ikan asap Pinekuhe (Gambar 1), yang diperoleh dari unit pengolahan ikan asap yang ada di Kabupaten Kepulauan Sangihe. Jumlah setiap pengambilan sampel pada masingmasing pengolah berjumlah 6 ekor ikan asap Pinekuhe sehingga total setiap kali pengambilan sampel pada pengolah A, B, C, dan D ada sebanyak 24 sampel uji. Setiap pengujian sampel tiap-tiap pengolah dilakukan 3 kali pengambilan. Pengamatan dan pengujian sampel ikan asap Pinekuhe dilakukan terhadap daging ikan. Daging selanjutnya dihaluskan dan ditimbang $25 \mathrm{~g}$ untuk uji Total Plate Count (TPC), $10 \mathrm{~g}$ untuk uji Staphylococcus $s p$. dan 25 g untuk uji total kapang.

\section{Analisis total bakteri (Ijong 2015)}

Sampel ikan asap Pinekuhe ditimbang sebanyak $25 \mathrm{~g}$, dimasukan ke dalam $225 \mathrm{ml}$ larutan $\mathrm{NaCl}$ 0,9\% steril dan dihomogenkan dengan menggunakan blender steril $\pm 3-5$ menit, kemudian diambil $1 \mathrm{ml}$ suspensi yang terbentuk (tingkat pengenceran 101) dan dimasukan ke dalam 9 ml larutan $\mathrm{NaCl}$ 0,9\% steril dan dihomogenkan dan seterusnya untuk pengenceran selanjutnya. Media Nutrient Agar (NA) yang sudah disterilisasikan didinginkan hingga suhu $\pm 40^{\circ} \mathrm{C}$ dan sejumlah $15 \mathrm{ml}$ dituang ke dalam tiap cawan petri, kemudian diputar 3 kali ke kiri, 3 kali ke kanan, didorong ke belakang satu kali, ke depan satu kali, selanjutnya didiamkan hingga media menjadi padat/ keras. Semua cawan petri dimasukan ke 
dalam inkubator dengan posisi terbalik (permukaan agar menghadap ke bawah). Inkubasi dilakukan pada suhu $37^{\circ} \mathrm{C}$ selama 24 dan 48 jam. Jumlah koloni yang terbentuk pada masing-masing cawan petri setelah inkubasi selama 24 jam dan 48 jam dihitung secara langsung, untuk mendapatkan hasil yang baik, maka setiap pengenceran dibuat duplo. Koloni bakteri dalam cawan petri dihitung setelah masa inkubasi berakhir. Jumlah koloni bakteri yang dihitung yaitu antara 30-300 koloni bakteri.

Analisis total koloni Staphylococcus sp (Ijong 2015)

Tujuan dari analisa total Staphylococcus $s p$ ini adalah menentukan secara kuantitatif koloni bakteri yang tumbuh pada Manitol Salt Agar. Prosedur analisis total Staphylococcus sp, sebagai berikut: sampel ditimbang masing-masing 10 gram dalam wadah steril. Secara aseptik, dimasukan ke dalam $90 \mathrm{ml}$ larutan $\mathrm{NaCl}$ $0,9 \%$ steril dan dihomogenkan dengan menggunakan blender $\pm 3-5$ menit (suspensi yang terbentuk akan memiliki tingkat pengenceran $10^{-1}$ ). Dengan pipet steril, ambil $1 \mathrm{ml}$ suspensi yang terbentuk, lalu dimasukan ke dalam $9 \mathrm{ml}$ larutan $\mathrm{NaCl}$ $0,9 \%$ steril dan dihomogen dengan cara mengocok tabung tersebut (suspensi yang terbentuk memiliki tingkat pengenceran $10^{-}$ $\left.{ }^{2}\right)$. Demikian seterusnya untuk pengenceran selanjutnya. Dari setiap pengenceran ambil masing-masing 0,1 atau $1,0 \mathrm{ml}$ suspensi dan pindahkan ke dalam media MSA yang telah diberi label jenis sampel dan tingkat pengencerannya. Dengan menggunakan batang penyebar gelas steril, disebarkan suspensi bakteri di seluruh permukaan media secara merata, sementara penyebaran suspensi dilakukan, cawan petri diputar perlahan-lahan. Masukan semua cawan petri ke dalam inkubator dengan posisi terbalik (permukaan agar menghadap ke bawah). Inkubasi pada suhu $37^{\circ} \mathrm{C}$ selama 24 dan 48 jam. Jumlah koloni yang terbentuk pada masing-masing cawan petri dihitung pada 24 jam dan 48 jam inkubasi. Untuk mendapatkan hasil yang baik, maka setiap pengenceran dibuat duplo.

\section{Total koloni $(T V C / g)=J u m l a h$ koloni $x$ $1 /$ faktor pengenceran}



Gambar 1. Ikan asap Pinekuhe

Analisis total koloni kapang (Modifikasi Fardiaz 1993)

Semua peralatan yang akan digunakan dalam analisis mikrobiologi disterilkan dengan menggunakan autoklaf pada suhu $121^{\circ} \mathrm{C}$ selama 15 menit dengan tekanan 15 psi. PDA disiapkan sebagai berikut: sejumlah 3,9 gram Potato Dextro Agar (PDA) ditambahkan pada $100 \mathrm{ml}$ akuades kemudian didihkan. Setelah itu disterilkan dalam autoklaf pada suhu $121^{\circ} \mathrm{C}$ selama 15 menit dengan tekanan 15 psi. Siapkan tabung reaksi yang diberi kode I-III yang berisi masing-masing $9 \mathrm{ml} \mathrm{NaCL} \mathrm{0,9 \%}$ kemudian disterilkan. Sampel diblender sampai halus, kemudian ditimbang sebanyak 10 gram dan dimasukkan ke dalam erlemeyer $250 \mathrm{ml}$ berisi $90 \mathrm{ml}$ larutan $\mathrm{NaCL}$ 0,9\% steril. Sampel ini merupakan pengenceran 10-1. Kemudian dari larutan tersebut diambil $1 \mathrm{ml}$ dan dipindahkan ke tabung reaksi I dengan cara dipipet untuk mendapatkan pengenceran 10-2. Dari tabung reaksi I dipipet lagi $1 \mathrm{ml}$ dan demikian seterusnya untuk pengenceran selanjutnya. Dari setiap pengenceran diambil masingmasing $1 \mathrm{ml}$ larutan secara aceptic dimasukkan dalam dua cawan petri steril. Selanjutnya dimasukkan PDA steril (suhu $43-46^{\circ} \mathrm{C}$ ) sebanyak $\pm 15 \mathrm{ml}$, ke dalam cawan petri lalu dihomogenkan dengan cara digoyang ke kiri, ke kanan, ke belakang, dan dibiarkan sampai membeku. Setelah media 
membeku, petri disusun terbalik dalam inkubator bersuhu $25-30^{\circ} \mathrm{C}$ dan diinkubasi selama 24-48 jam. Kemudian dihitung jumlah koloni kapang yang tumbuh pada media agar di cawan petri. Koloni yang dihitung berjumlah 30-300 koloni. Jumlah total koloni kapang yang dihitung, kemudian dikalikan dengan faktor pengenceran.

\section{Total koloni kapang $=$ Jumlah koloni kapang $x$ $1 /$ Tingkat pengenceran}

\section{Analisis data}

Metode penelitian ini menggunakan metode eksperimental yang memberikan informasi berupa gambaran atau pengamatan. Datayangdiperoleh dari analisa laboratorium dipaparkan secara deskriptif. Hasil pengamatan dari perhitungan jumlah total bakteri, total Staphylococcus $s p$, dan total kapang, disajikan dalam bentuk tabel dan grafik dan selanjutnya dibandingkan dengan Standar Nasional Indonesia (SNI) untuk produk ikan asap.

\section{HASIL DAN PEMBAHASAN}

\section{Total bakteri}

Hasil analisis mikrobiologis dari nilai angka lempeng total terhadap ikan asap Pinekuhe yang diambil dari Pengolah A, Pengolah B, Pengolah C, dan Pengolah $\mathrm{D}$ maka didapatkan hasil nilai dari analisis total bakteri dengan menggunakan metode angka lempeng total dapat dilihat pada Gambar 2.

Hasil dari analisa ALT pada pengolah A pengambilan 1, 2, dan 3, memiliki nilai ratarata TPC yaitu $1,3 \times 10^{4} \mathrm{CFU} / \mathrm{g}$. Sedangkan untuk hasil analisa ALT pada Pengolah B pengambilan 1,2 , dan 3, memiliki nilai ratarata TPC 2,6 x $10^{4} \mathrm{CFU} / \mathrm{g}$. Untuk Pengolah $\mathrm{C}$ hasil ALT pada pengambilan 1, 2, dan 3 dengan rata - rata nilai TPC yaitu $6,9 \times 10^{4}$. Sedangkan untuk Pengolah D pengambilan 1,2 , dan 3 , dengan nilai rata-rata TPC 1,2 $\mathrm{x} 10^{4} \mathrm{CFU} / \mathrm{g}$. Pertumbuhan koloni pada perhitungan angka lempeng total sampel ikan asap Pinekuhe pada media Nutrient Agar (NA) dapat dilihat pada Gambar 3.

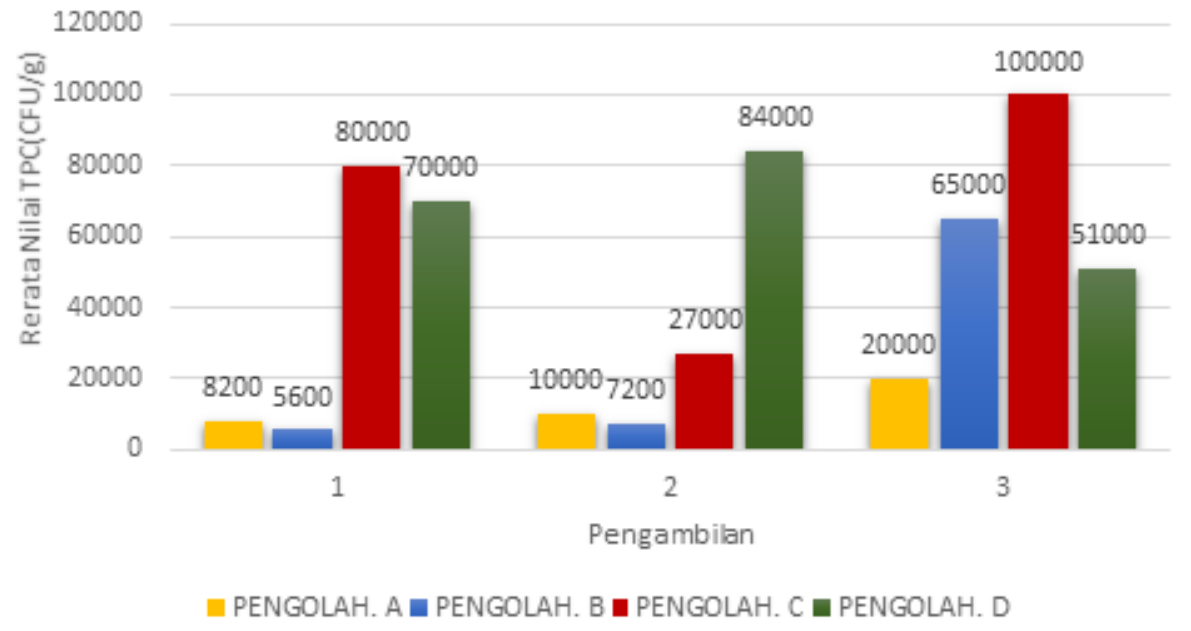

Gambar 2. Nilai rata-rata TPC ikan asap Pinekuhe hasil olahan tradisional nelayan Kabupaten Sangihe

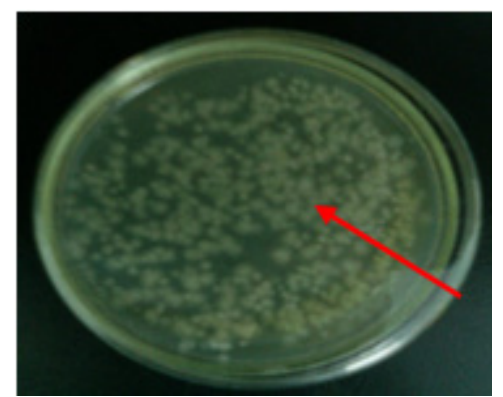

Gambar 3. Pertumbuhan koloni bakteri pada media NA 
Hasil penelitian bahwa total bakteri ikan asap Pinekuhe yang diambil dari Pengolah A dan Pengolah B, Pengolah $\mathrm{C}$, dan Pengolah $\mathrm{D}$ dengan pengambilan sampel 1, 2, 3 semuanya masih memenuhi syarat. Berdasarkan persyaratan mutu yang dikeluarkan oleh Badan Standar Nasional Indonesia (SNI 2725.1:2009) jumlah bakteri maksimum untuk ikan asap yaitu maksimal $1,0 \times 10^{5}$. Sehingga dapat disimpulkan bahwa ikan asap layang Pinekuhe tersebut layak dikonsumsi secara langsung. Keberadaan bakteri dalam suatu bahan pangan dapat ditandai dari jumlah koloni per gram bahan pangan melalui uji TPC (Febriyanti et al. 2015). Koloni yang tumbuh dapat juga digunakan untuk isolasi serta identifikasi bakteri karena koloni yang terbentuk mungkin berasal dari suatu bakteri yang mempunyai penampakan pertumbuhan spesifik. Perhitungan total bakteri dengan metode hitungan cawan sel mikroba yang berkembang biak dan membentuk koloni dapat dilihat langsung tanpa menggunakan alat mikroskop (Nara 2013).

Bakteri merupakan mikroorganisme yang keberadaanya penting untuk kita perhatikan terutama pada bahan pangan, disamping karena bakteri dapat berperan sebagai agen pembusuk pada produkproduk olahan, juga beberapa di antaranya bakteri ada yang bersifat patogen terhadap manusia. Menurut Buckle et al. (1987) menyatakan bahwa nilai TPC dipengaruhi oleh faktor ekstrinsik yaitu kondisi lingkungan dan cara penanganan dan penyimpanan produk.

\section{Total kapang}

Hasil dari analisis total kapang pada Pengolah A, B, C, dan D. pengambilan 1, 2 dan 3, menghasilkan nilai 0. Pertumbuhan koloni pada perhitungan total kapang sampel ikan asap Pinekuhe pada media Potato Dextroce Agar (PDA) dapat dilihat pada Gambar 4.

Hasil penelitian dapat dilihat bahwa ikan asap Pinekuhe yang diambil dari semua Pengolah masih memenuhi syarat untuk dikonsumsi. Berdasarkan persyaratan mutu yang dikeluarkan oleh Badan Standar Nasional Indonesia (SNI 7388:2009) jumlah total kapang maksimum untuk ikan asap yaitu maksimal $<1,0 \times 10^{2}$ koloni/g. Dapat disimpulkan bahwa ikan asap layang Pinekuhe tersebut layak dikonsumsi secara langsung. Salah satu penyebab kemunduran mutu pada produk ikan asap yaitu dimulai dari tumbuhnya kapang pada permukaan kulit. Ini kemungkinan oleh aspek lingkungan dimana ikan asap Pinekuhe disimpan secara sembarangan dalam kas/keranjang di tempat pengolah maupun penjualan tanpa memperhatikan pertukaran udara yang menyebabkan terjadinya pengembunan atau kelembaban dan ini adalah salah satu kondisi yang sangat baik hidupnya kapang pada ikan asap. Sopandi dan Wardah (2014), menjelaskan bahwa kapang dianggap penting dalam pangan karena kapang dapat tumbuh pada berbagai kondisi, bahkan pada kondisi ketika beberapa bakteri tidak dapat tumbuh. Selain itu juga ada beberapa kapang yang ditemukan dalam pangan merupakan mikroorganisme yang merugikan, termasuk perusak pangan.

Menurut Fardiaz (1993), kapang adalah fungi multiseluler yang mempunyai flamen, dan pertumbuhanya pada makanan mudah dilihat karena penampakannya yang bersarabut seperti kapas. Optimum pertumbuhan kapang $20-30^{\circ} \mathrm{C}$ dengan kisaran $\mathrm{pH}$ yang luas yaitu $2,0-8,5$, tetapi biasanya pertumbuhan kapang akan lebih baik pada kondisi asam $\mathrm{pH}$ rendah. Menurut Siagian (2002), selain oleh bakteri, kapang juga dapat menimbulkan penyakit, yaitu pertama infeksi oleh fungi yang disebut mikosis dan kedua keracunan yang disebabkan oleh tertelannya metabolik beracun dari fungi atau mikotoksikosis. Sopandi dan Wardah (2014), menambahkan bahwa beberapa strain kapang juga dapat memproduksi mikotoksin dan terlibat dalam keracunan pangan. Mikotoksikosis biasanya tersebar melalui makanan, sedangkan mikosis tidak melalui makanan tetapi melalui kulit atau lapisan epidermis, rambut dan kuku akibat sentuhan, pakaian, atau terbawa angin.

\section{Total stapilokoki}

Hasil analisis nilai total Stapilokoki pada ikan asap Pinekuhe yang diambil dari Pengolah A, Pengolah B, Pengolah C, dan Pengolah. D dapat dilihat pada Gambar 5.

Hasil analisis total Staphylococcus pada pengolah A dan Pengolah B. pengambilan 1, 2, dan 3 menghasilkan nilai 0. Sedangkan Pengolah $\mathrm{C}$ hasil Total Stapilokoki pada pengambilan 1, 2, dan 3 memiliki rata-rata nilai total Staphylococcus yaitu $1,1 \times 10^{2} \mathrm{TVC} / \mathrm{g}$. Sedangkan untuk Pengolah D pengambilan 1 , 2, dan 3 , nilai rata-rata total Stapilokoki $1,2 \times 10^{2} \mathrm{TVC} / \mathrm{g}$. 
Manitol Salt Agar (MSA) merupakan medium padat selektif yang digunakan dalam industri makanan untuk isolasi dan identifikasi bakteri patogen Staphylococcus seperti S. aureus, yang ditemukan dalam daging, susu, dan bahan makanan lainya (Safitri dan Novel 2010). Karakteristik koloni Staphylococcus aureus yang tumbuh pada media MSA dapat dilihat pada Gambar 6.

Dari hasil analisis total Staphylococcus, dapat dilihat bahwa sampel yang berasal dari Pengolah $\mathrm{C}$ dan
Pasar Pengolah D kandungan bakteri Staphylococcus bervariasi, dari total Staphylococcus ini tetapi masih memenuhi standar, dengan Standar Nasional Indonesia (SNI - 2725.1:2009) untuk Staphylococcus aureus yaitu Maksimal 1,0 x $10^{3}$. Pertumbuhan bakteri ini kemungkinan dapat terjadi pada saat ikan diolah, penyimpanan dan pada saat distribusi ke konsumen, penjual tidak memperhatikan sanitasi dan higienis (Karimela et al. 2017).

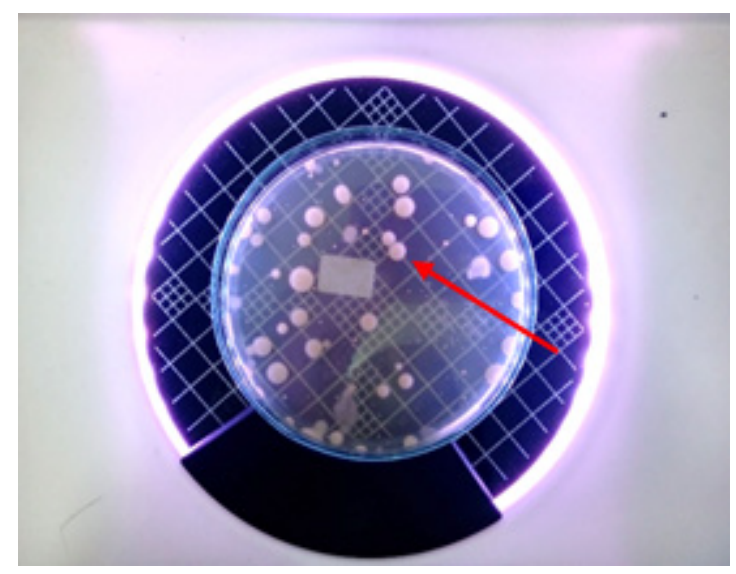

Gambar 4. Koloni kapang pada media PDA

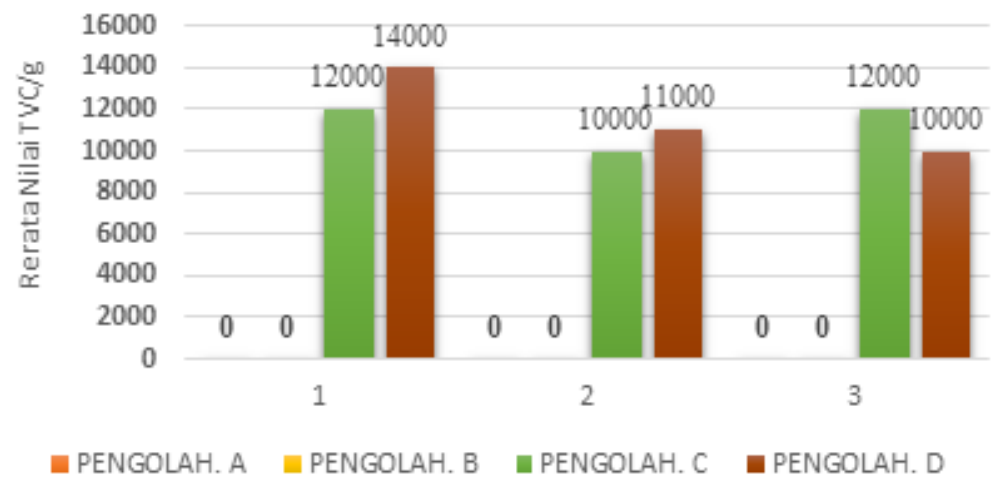

Gambar 5. Nilai total Staphylococcus ikan Pinekuhe asap

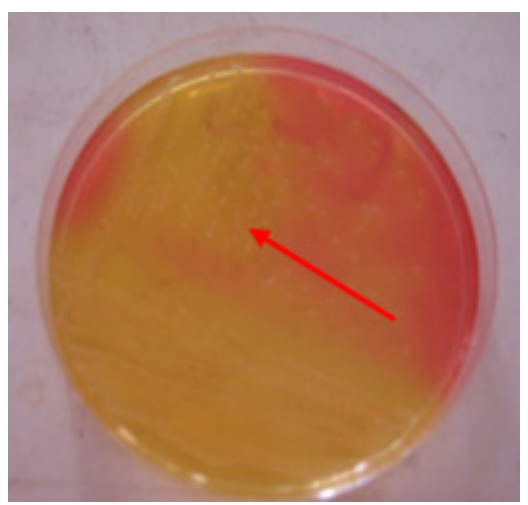

Gambar 6. Pertumbuhan koloni Staphylococcus aureus pada media MSA diduga sebagai koloni Staphylococcus yaitu koloni yang memiliki karakteristik warna kuning keemasan 
Pengawetan ikan dengan pengasapan dapat mengurangi pertumbuhan bakteri. Namun selama dan setelah proses pengolahannya kemungkinan kontaminasi bakteri patogen dapat terjadi. Kehadiran bakteri patogen di dalam ikan atau hasil metabolismenya dapat menimbulkan gangguan kesehatan berupa keracunan (intoksikasi) dan infeksi. Salah satu bakteri yang dapat menyebabkan keracunan dan dicurigai terdapat pada ikan asap adalah bakteri Staphylococcus aureus (Ekawati et al. 2005). Gutiérrez et al. (2012) menjelaskan bahwa Staphylococcus aureus merupakan salah satu bakteri patogen yang menyebabkan penyakit pada manusia yang ditularkan melalui makanan.

Menurut Fellows (2012), penyebab utama kontaminasi antara lain prosedur yang kurang higienis dan mikroorganisme yang terbawa oleh udara selama proses pengemasan produk. Selain itu juga penyakit yang diakibatkan oleh mengkonsumsi pangan asap yang tidak tepat disebabkan oleh Staphylococcus aureus, bakteri ini secara alami terdapat pada ikan mentah dan sumber infeksinya adalah orang yang menangani ikan. Tangan manusia merupakan sumber pencemaran bakteri yang berasal dari luka atau infeksi kulit, dan salah satu bakteri yang berasal dari tangan manusia, yaitu Staphylococcus aureus, dapat menyebabkan keracunan pangan. Oleh karena itu orang tersebut dapat menjadi sumber pencemaran pangan jika ditugaskan menangani atau mengolah pangan. Tingginya tingkat cemaran $S$. aureus pada olahan makanan sangat erat hubunganya dengan manusia yang menanganinya.

Staphylococcus aureus hidup sebagai saprofit di dalam saluran-saluran pengeluaran lendir dari tubuh manusia seperti hidung, mulut, dan tenggorokan dan dapat dikeluarkan pada waktu batuk atau bersin. Ijong (2015) menambahkan Staphylococcus biasanya hidup sebagai parasit pada manusia dan hewan, kadangkadang dapat menyebabkan infeksi serius. $S$. aureus dapat memproduksi enterotoksin yang menyebabkan keracunan makanan bagi manusia dan hewan.

Sedangkan menurut Pratiwi (2008), bahwa bakteri Staphylococcus aureus, mengeluarkan toksin pada makanan berprotein tinggi (daging, telur, susu, ikan). Bakteri Staphylococcus aureus, merupakan salah satu kuman yang cukup kebal di antara mikroorganisme lainya, dan tahan pada pemanasan $60^{\circ} \mathrm{C}$ selama 30 menit. Pencegahan untuk menghindari kontaminasi bakteri Staphylococcus aureus pada makanan dapat dilakukan dengan penyimpanan makanan pada suhu di bawah $4^{\circ} \mathrm{C}$. Hal ini yang tidak dapat diabaikan ialah selalu menjaga kebersihan tubuh maupun lingkungan, karena manusia merupakan reservoar yang baik untuk bakteri Staphylococcus aureus. Kontaminasi Staphylococcus aureus pada ikan asap sangat dipengaruhi oleh faktor praktik higiene selama produksi. Kontaminasi semakin meningkat dengan semakin panjangnya rantai distribusi, yaitu ketika ikan asap dipasarkan. Oleh karena kontak orang per orang dan ikan asap akan semakin terkontaminasi dengan bakteri patogen.

\section{KESIMPULAN DAN SARAN}

\section{Kesimpulan}

Hasil total Staphylococcus, yang berasal dari Pengolah C dan Pengolah D kandungan bakteri Staphylococcus relatif tinggi melebihi ambang batas cemaran, bila dibandingkan dengan Standar Nasional Indonesia (SNI-2725.1:2009) untuk Staphylococcus aureus yaitu maksimal 1,0 $\mathrm{x} 10^{3}$, sudah jelas bahwa ternyata sampel ikan asap layang Pinekuhe pada kedua Pengolah tersebut yaitu Pengolah C dan Pengolah D tidak layak untuk di konsumsi secara langsung. Hanya dapat dikonsumsi apabila ada pengolahan lebih lanjut seperti pemanasan di atas $60^{\circ} \mathrm{C}$. Untuk Total bakteri dan Total Kapang masih memenuhi syarat. Berdasarkan persyaratan mutu yang dikeluarkan oleh Badan Standar Nasional Indonesia.

\section{Saran}

Dilihat dari data yang ada bahwa, jumlah total Staphylococcus yang mendominasi ikan asap Pinekuhe cukup signifikan cemarannya sehingga disarankan kepada pengolah agar memperhatikan sanitasi dan higienis pengolah maupun peralatan produksi yang digunakan selama proses pengolahan berlangsung mengingat bakteri Staphylococcus merupakan bakteri yang hidup normalnya pada manusia. 


\section{DAFTAR PUSTAKA}

[BSN] Badan Standardisasi Nasional. 2009. SNI. 2725. 1. Ikan Asap-Bagian 1. Spesifikasi. Jakarta (ID): Badan Standar Nasional.

Buckle KA, Edwards RA, Fleet GH, Wooton M. 1987. Ilmu Pangan. Terjemahan Hari Purnomo. Universitas Indonesia. Press Jakarta.

Ekawati P, Martini, Yuliawati S. 2005. Kontaminasi Staphylococcus aureus pada Ikan Asap di Tingkat Produsen dan Penjual di Semarang. Jurnal Kesehatan Masyarakat. 2: 4-5.

Gutiérrez D, Delgado S, Sánchez DV, Martínez B, Cabo ML, Rodriguez A, Herrera JJ, García P. 2012. Incidence of Staphylococcus aureus and Analysis of Associated Bacterial Communities on Food Industry Surfaces. Jurnal ASM. 78(24): 8547-8554.

Fardiaz S. 1993. Analisis Mikrobiologi Pangan. Jakarta (ID): PT Raja Grafindo Persada.

Febriyanti D, Rahayu SP, Khoiron. 2015. Total Plate Count and Staphylococcus aureus in Ariidae Salted Fish (Ariusthallasinus) in Fish Auction Puger, Jember Regency. Artikel Ilmiah. Fakultas Kesehatan Masyarakat. Universitas Jember.

Fellows PJ. 2012. Teknologi Pengolahan Pangan: Prinsip dan Praktik, 3rd Ed. Jakarta (ID): Buku Kedokteran.

Ijong FG. 2015. Mikrobiologi Perikanan dan Kelautan. Jakarta (ID): Rineka Cipta.

Karimela EJ, Ijong FG, Agustin AG. 2013. Staphylococcus sp. pada Ikan Layang (Decapterus russelii) Asap Pinekuhe
Produk khas Sangihe. Jurnal Media Teknologi Hasil Perikanan. 1(2): 59.

Nara SM. 2013. Karakteristik Mutu Mikrobiologis dan Biokimiawi Produk Olahan Tradisional Ikan Asin Basah (Ina Sua) dari Kepulauan Maluku Tengah [Tesis]. Manado: Pascasarjana Unsrat.

Prasetyo DYB, Darmanto YS, Swastawati F. 2015. Efek Perbedaan Suhu dan Lama Pengasapan terhadap Kualitas Ikan Bandeng (Chanos chanos Forsk) Cabut Duri Asap. Jurnal Aplikasi Teknologi Pangan. 4(3): 94.

Pratiwi TS. 2008. Mikrobiologi Farmasi. Jakarta (ID): Erlangga.

Safitri R, Novel SS. 2010. Medium Analisis Mikroorganisme (Isolasi dan Kultur). Jakarta (ID): Trans Info Media.

Sulistijowati S, Djunaedi OS, Nurhajati J, Afrianto E, Udin Z. 2011. Mekanisme Pengasapan Ikan. ISBN 978-6028743-86-0. Bandung (ID): Unpad Press.

Siagian A. 2002. Mikroba Patogen pada Makanan dan Sumber Pencemarannya. Fakultas Kesehatan Masyarakat Universitas Sumatera Utara.

Sopandi T, Wardah. 2014. Mikrobiologi Pangan [Teori dan Praktik]. Yogyakarta (ID): CV. Andi Offset.

Teurupun A, Timbowo SM, Palenewen JCV. 2013. Identifikasi Kapang pada Rumput Laut Eucheuma cottonii (Kappaphycus alvarezii) Kering dari Desa Rap Rap Arakan Kecamatan Tatapaan Kabupaten Minsel. Jurnal Media Teknologi Hasil Perikanan. 1(1): 12 . 